\title{
Recurrent Localized Pseudomyxoma Peritonei in the Female Pelvis
}

\author{
Igor Mishin ${ }^{\mathrm{a}} \quad$ Gheorghe Ghidirim $^{\mathrm{a}}$ Eugen Gladun ${ }^{\mathrm{b}} \quad$ Anna Mishina ${ }^{\mathrm{b}} \quad$ Marin Vozian $^{\mathrm{a}}$ \\ ${ }^{a}$ First Department of Surgery 'N. Anestiadi' and Laboratory of Hepato-Pancreato-Biliary Surgery, National Center of Emergency Medicine, \\ ${ }^{b}$ Department of Surgical Gynecology, Medical University 'N. Testemitsanu', Kishinev, Moldova
}

Keywords
Pseudomyxoma $\cdot$ Recurrence $\cdot$ Localization $\cdot$ Pelvis

Summary

Objective: Pseudomyxoma peritonei (PMP) is a rare, chronic, relapsing, diagnostically challenging, and poorly understood disease characterized by disseminated mucinous ascites and peritoneal implants. PMP usually develops secondary to mucinous neoplasms of the appendix and/or the ovary. Only few reports of limited PMP were published. Case Report: We describe the case of a 53-year-old woman who presented with a limited mucinous collection in the pelvis seen on computed tomography and who underwent surgery for mucocele of the appendix, bilateral mucinous ovarian tumors, and single mucinous implant on the great omentum 16 years previously. Serum tumor markers: CEA was elevated and CA 19-9 was within the normal range. At surgery, a wellcircumscribed collection of mucin was found in the pelvis, and removal of mucinous material with intraoperative hyperthermic intraperitoneal chemotherapy (HIPEC) and postoperative intraperitoneal irrigation with 5-fluorouracil was performed. Histological examination revealed disseminated peritoneal adenomucinosis according to Ronnett's classification. After surgery, the patient has been free of recurrence for 2 years. Conclusion: Our case report highlights that PMP requires careful observation, as it might be detected after a long-term follow-up period post-appendectomy for appendiceal mucocele.

\author{
Schlüsselwörter \\ Pseudomyxom · Rezidiv · Lokalisation · Becken
}

\section{Zusammenfassung}

Hintergrund: Pseudomyxoma peritonei (PMP) ist eine seltene, chronische, schubförmig verlaufende, schwer zu diagnostizierende und schlecht verstandene Krankheit, die durch disseminierten muzinösen Aszites und peritoneale Implantate charakterisiert ist. PMP entwickelt meist sekundäre bis muzinöse Neoplasien des Appendix und/oder der Eierstöcke. Nur wenige Berichte über begrenzte PMP wurden bislang veröffentlicht. Fallbericht: Wir stellen den Fall einer 53 -jährigen Frau vor, die mit einer begrenzten muzinösen Ansammlung im Becken, die während der Computertomographie festgestellt wurde, vorstellig wurde und die wegen einer Appendix-Mukozele, bilateraler muzinöser Ovarialtumoren und eines einfachen muzinösen, 16 Jahre zurückliegenden Implantats auf dem Omentum majus operiert wurde. Tumormarker im Serum: CEA war erhöht, CA 19-9 befand sich im normalen Bereich. Bei der Operation wurde eine gut abgegrenzte Ansammlung von Muzin im Becken gefunden; das muzinöse Material wurde mittels intraoperativer hyperthermischer intraperitonealer Chemotherapie (HIPEC) und postoperativer intraperitonealer Spülung mit 5-Fluorouracil entfernt. Die histologische Untersuchung ergab gemäß der Klassifizierung von Ronnett eine disseminierte peritoneale Adenomucinosis. Nach der Operation war die Patientin 2 Jahre lang beschwerdefrei. Schlussfolgerung: Unser Fallbericht unterstreicht, dass PMP eine sorgfältige Beobachtung erfordert, da die Möglichkeit besteht, dass es nach Appendektomie aufgrund einer AppendixMukozele auch nach einer Langzeit-Follow-up-Periode erkannt wird.

\section{KARGER \\ Fax +497614520714 \\ Information@Karger.de}

www.karger.com
(C) 2011 S. Karger GmbH, Freiburg

1662-6664/11/0276-0473\$38.00/0

Accessible online at:

www.karger.com/vim
Igor Mishin, $\mathrm{MD}, \mathrm{PhD}$

str. Muncesti 52, ap. 60

2001, Kishinev, Moldova

Tel. +373 22-832465, Fax -522008

mishin_igor@mail.ru 


\section{Introduction}

Pseudomyxoma peritonei (PMP) is a rare neoplastic condition in which gelatinous intraperitoneal fluid collections associated with disseminated mucinous tumor implants are observed. Although ruptured appendiceal mucocele is the most common cause of this condition, pathologic findings arising from other origins such as the ovary, pancreas, intestine, bile duct, and urachus may also cause PMP [1]. When mucinous fluid-like materials localize in the female pelvic cavity, which is an infrequent condition, this may mimic ovarian carcinomatous peritonitis and may be treated as a gynecologic disease [2]. Only sporadic reports of limited PMP were published [2]. We hereby report an additional case of localized PMP in the female pelvis.

\section{Case Report}

A 53-year-old woman was referred to our hospital in order to evaluate a pelvic mass. She was complaining about pain in the lower abdomen and dysuria. Her past medical history was significant in terms of subtotal hys-

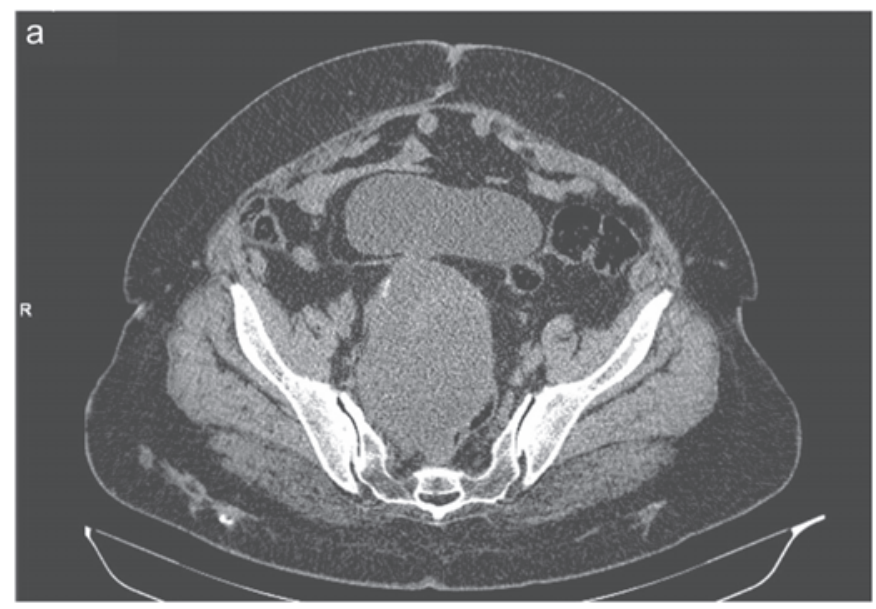

Fig. 1. CT showing a localized pelvic well-defined cystic hypodense mass.

a Axial view. b Sagittal view.

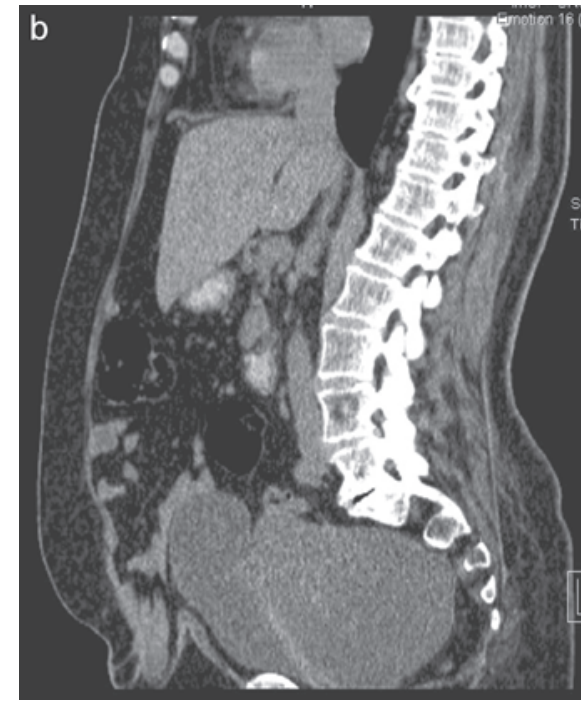

terectomy, bilateral salpingo-oophorectomy, omentectomy and appendectomy for mucocele of the appendix, bilateral mucinous ovarian tumors, and single mucinous implant on the great omentum 16 years previously. The pathologic examination of the surgical specimen demonstrated appendiceal mucinous cystadenoma and bilateral ovarian mucinuos cysts. 10 years later, she presented with pain in the lower abdomen and limited fluid collection in the pelvis; during surgery, a mucin-filled cavity was found in the pelvis and removal of the mucinous content was performed.

Admission routine tests were within the normal ranges, while tumor markers were either elevated (CEA: $10.4 \mathrm{ng} / \mathrm{l}$; upper limit of normal range: $0.5 \mathrm{ng} / \mathrm{l}$ ) or within normal range (CA 19-9: $23.9 \mathrm{U} / \mathrm{ml}$; upper limit of normal range: $37 \mathrm{U} / \mathrm{ml}$ ). Computed tomography $(\mathrm{CT})$ revealed a $120 \times 83 \mathrm{~mm}$ oval-shaped encapsulated fluid collection in the pelvis between rectum and bladder with calcification in the wall (fig. 1a,b).

The CT findings were confirmed during surgery. An encapsulated mass in the pelvic cavity was filled with mucinous material, and no solid implants or mucin were found in the free peritoneal cavity. The mucinous content was removed completely and intraoperative hyperthermic intraperitoneal chemotherapy (HIPEC) as well as postoperative intraperitoneal chemotherapy with 5 -fluorouracil $(5-\mathrm{FU})\left(750 \mathrm{mg} / \mathrm{m}^{2}\right)$ were performed for 5 postoperative days. Histological examination revealed disseminated peritoneal adenomucinosis according to Ronnett's classification (fig. 2) [3]. The postoperative course was uneventful. The patient was scheduled for close follow-up and showed no relapse as well as normal levels of CEA and CA 19-9 at 24 months.

\section{Discussion}

PMP is a rare disease characterized by the spread of mucinous ascites with peritoneal and omental mucinous implants throughout the abdomen [4]. Werth was the first to describe this entity in 1884 [4]. There is a redistribution of the tumor in the abdominal cavity to predictable sites [4]. Predisposition sites are the omentum ('omental cake'), the subhepatic region, the subdiaphragmal regions, and the ovaries. Patients usually present with an expanding abdomen ('jelly belly'), or

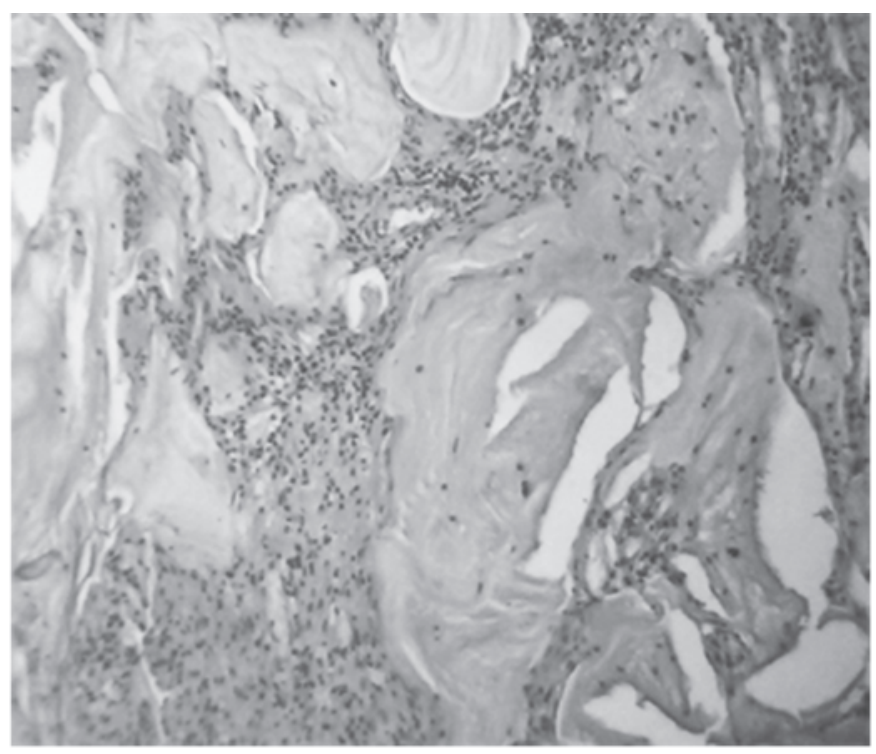

Fig. 2. Histologic examination revealed disseminated peritoneal adenomucinosis $(\mathrm{HE} \times 100)$. 
PMP is diagnosed at abdominal surgery for other reasons $[5,6]$. PMP is mostly confined to the peritoneal cavity; however, metastases have been reported in rare cases [7-10].

The term PMP is often applied to a heterogeneous group of pathologic lesions characterized by the presence of abundant extracellular mucus with or without epithelial cells [4]. There is no uniform pathological diagnosis; peritoneal seeding from a ruptured adenoma and from a well-differentiated mucinous adenocarcinoma of the colon, most frequently the appendix, can lead to PMP. Both the appendix and the ovaries may be the origin of this disease. In most women, simultaneous occurrence in the appendix and ovaries are found [11] A recent consensus has been reached regarding the immunohistochemical molecular genetic evidence that the appendix is the most frequent site of origin, while the ovaries are probably secondary tumor deposits $[4,12,13]$.

Other origins have been described, including lung, fallopian tube, and urachus [14-16]. Ronnett et al. [3] introduced a classification system replacing the term PMP in favor of three diagnostic groups with decreasing prognosis: disseminated peritoneal adenomucinosis (DPAM), peritoneal mucinous carcinomatosis with intermediate or discordant features (PMCA$\mathrm{I} / \mathrm{D})$, and peritoneal mucinous carcinomatosis (PMCA).

Several reports about this disease concerned the coexistence of mucinous tumors of the ovary and appendix. The causal link between ovarian and appendiceal tumors is not clear as to whether these tumors have independent origins or not. It is believed that unilateral mucinous tumors originate from the ovary and that bilateral ovarian mucinous tumors are secondary $[1,11,17]$. Ronnett et al. [11] argued that ovarian mucinous tumors with PMP mainly reflect secondary involvement. The pathogenesis of the PMP is related to perforation of the appendiceal mucocele and spreading of the mucin from the pelvis to the subdiaphragmatic area ('redistribution phenomenon') [18].

In some cases, synchronous mucinous tumors of the ovary and the appendix may occur and occult primary appendiceal tumors may be revealed by postoperative histopathologic examination [17]. When mucinous fluid-like materials localize in the female pelvic cavity with ovarian involvement, this may mimic ovarian carcinomatous peritonitis and may be treated as a gynecologic disease [2].

PMP occurring more than 20 years after appendectomy is infrequent, with the longest interval reported between appendectomy and diagnosis of PMP being 35 years [19, 20]. In our case, PMP first developed 10 years after appendectomy and for the second time after 5 additional years. Thus, these patients require careful observation, as PMP can possibly be detected after a long-term follow-up period of more than 20 years.

At presentation, the clinical features are diverse. Patients most frequently reported progressive abdominal distension (23-55\%); a presumed diagnosis of acute appendicitis and of pelvic (ovary) mass was made in $20-27 \%$ and in $39 \%$ of the patients prior to the diagnosis of PMP, respectively, while
$14 \%$ of the patients initially presented with signs and symptoms of gastrointestinal obstruction. The diagnosis of PMP was made during the evaluation of inguinal hernia (5-25\%), nonspecific abdominal pain (3-9\%), and occult gastrointestinal bleeding ( $2 \%, 2 / 97$ patients) $[4,21,22]$. Though CEA and CA 19-9 concentrations have not been measured in many cases, these serum markers have occasionally been found to be elevated [1]. High serum concentrations of CEA suggest a poor prognosis and possible recurrence of the disease [23]. In the present case, the CEA level was elevated.

CT findings in PMP are diverse, including masses distributed throughout the abdomen, a thick, cystic wall or septa, scalloping of the surface of the liver, and ascites [24, 25], as well as non-specific calcification that may be seen on CT [26], similar to our case.

A Pubmed and MeSH Terms search showed only one report of two cases of localized PMP in the female pelvis [2].

Surgery is the mainstay of treatment, but the recurrence rate is high [1]. Despite the usually slow growth of this tumor, this disease is usually fatal. In recent years, efforts have been concentrated on surgery combined with adjuvant therapy. Sugarbaker [27] advocates that surgery combined with intraperitoneal chemotherapy improves survival.

Chemotherapy and radiotherapy have also been shown to be helpful $[28,29]$. Some have reported the use of 5-FU, cyclophosphamide, L-phenylalanine mustard, doxorubicin, and cisplatinum [23]. The present patient received intraoperative HIPEC and postoperative intraperitoneal chemotherapy with 5-FU $\left(750 \mathrm{mg} / \mathrm{m}^{2}\right)$ for 5 days.

PMP remains a disease that follows 'an unremitting but prolonged clinical course' and is characterized by a high recurrence rate. Thus, Gough et al. [23] reported a recurrence rate of $76 \%$, with half of the recurrences occurring after 2.5 years.

Prognosis of the PMP is directly related to the histological variant: survival at 5 and 10 years was $75 \%$ and $68 \%$ in the case of DPAM, $50 \%$ and $21 \%$ in the case of PMCA-I/D, and $14 \%$ and $3 \%$ in the case of PMCA, respectively [3].

Despite a much improved understanding regarding the biology of this condition, the impact of therapy is still not completely understood. Even though complete cytoreduction is associated with prolonged overall survival, disease recurrence is common and multiple operations are frequently required. Thus, these patients require careful observation, as the disease can possibly be detected after a long-term follow-up period.

\section{Disclosure Statement}

The authors declare no conflict of interest.

The trial protocol has been approved by the ethical committee and thus meets the standards of the Declaration of Helsinki in its revised version of 1975 and its amendments of 1983, 1989, and 1996 [JAMA 1997;277:925-926].

The patient gave the informed consent for the data to be published. 


\section{References}

1 Hinson FL, Ambrose NS: Pseudomyxoma peritonei. Br J Surg 1998;85:1332-1339.

2 Takeuchi M, Matsuzaki K, Yoshida S, Nishitani H, Uehara H: Localized pseudomyxoma peritonei in the female pelvis simulating ovarian carcinomatous peritonitis. J Comput Assist Tomogr 2003;27:622-625.

3 Ronnett BM, Yan H, Kurman RJ, Shmookler BM, Wu L, Sugarbaker PH: Patients with pseudomyxoma peritonei associated with disseminated peritoneal adenomucinosis have a significantly more favorable prognosis than patients with peritoneal mucinous carcinomatosis. Cancer 2001;92:85-91.

4 Smeenk RM, Bruin SC, van Velthuysen ML, Verwaal VJ: Pseudomyxoma peritonei. Curr Probl Surg 2008;45:527-575.

5 Sherer DM, Abulafia O, Eliakim R: Pseudomyxoma peritonei: a review of current literature. Gynecol Obstet Invest 2001;51:73-80.

6 Jacquet P, Averbach A, Stuart OA, Chang D, Sugarbaker PH: Hyperthermic intraperitoneal doxorubicin: pharmacokinetics, metabolism, and tissue distribution in a rat model. Cancer Chemother Pharmacol 1998;41:147-154.

7 Mets T, Van Hove W, Louis H: Pseudomyxoma peritonei. Report of a case with extraperitoneal metastasis and invasion of the spleen. Chest 1977;72:792-794.

8 Chevillotte G, Choux R, Spik G, Sahel J, Scheiner C, Montreuil J, Lebreuil G, Sarles H: Pseudomyxoma peritonei: a case with multiple metastases. Ultrastructural study and chemical analysis of the mucoid substance. Gastroenterol Clin Biol 1983;7: 445-450.

9 Kreissig P, Daucourt J, Garnier G: Pseudomyxoma peritonei with pulmonary metastasis (article in French). Presse Med 1991;20:1287.

10 Radosavljevic G, Nedeljkovic B, Kacar V: Pseudomyxoma of the pleural and peritoneal cavities. Thorax 1993;48:94-95.

11 Ronnett BM, Kurman RJ, Zahn CM, Shmookler BM, Jablonski KA, Kass ME, Sugar baker PH: Pseudomyxoma peritonei in women: a clinicopathologic analysis of 30 cases with emphasis on site of origin, prognosis, and relationship to ovarian mucinous tumors of low malignant potential. Hum Pathol 1995;26:509-524.

12 Young RH, Gilks CB, Scully RE: Mucinous tumors of the appendix associated with mucinous tumors of the ovary and pseudomyxoma peritonei. A clinicopathological analysis of 22 cases supporting an origin in the appendix. Am J Surg Pathol 1991; 15:415-429.

13 Prayson RA, Hart WR, Petras RE: Pseudomyxoma peritonei. A clinicopathologic study of 19 cases with emphasis on site of origin and nature of associated ovarian tumors. Am J Surg Pathol 1994;18:591-603.

14 Kurita M, Komatsu H, Hata Y, Shiina S, Ota S, Terano A, Sugimoto T, Oka T, Nanba Y: Pseudomyxoma peritonei due to adenocarcinoma of the lung: case report. J Gastroenterol 1994:29:344-348.

15 McCarthy JH, Aga R: A fallopian tube lesion of borderline malignancy associated with pseudo-myxoma peritonei. Histopathology 1988;13:223-225.

16 de Bree E, Witkamp A, Van De Vijver M, Zoetmulder F: Unusual origins of pseudomyxoma peritonei. J Surg Oncol 2000;75:270-274

17 Zissin R, Gayer G, Fishman A, Edelstein E, Shapiro-Feinberg M: Synchronous mucinous tumors of the ovary and the appendix associated with pseudomyxoma peritonei: CT findings. Abdom Imaging 2000;25:311-316.

18 Sugarbaker PH: Pseudomyxoma peritonei. A cancer whose biology is characterized by a redistribution phenomenon. Ann Surg 1994;219:109-111.

19 Taii A, Sakagami J, Shinoda M, Taniguchi H, Tosa M, Baba T, Motoyoshi T, Ito R, Mitsufuji S, Kataoka K, Okanoue T: Pseudomyxoma peritonei occurring after an uneventful 23 years interval from appendectomy. Intern Med 2007:46:1109-1112.

-20 Solkar MH, Akhtar NM, Khan Z, Parker MC: Pseudomyxoma extraperitonei occurring 35 years after appendicectomy: a case report and review of literature. World J Surg Oncol 2004;2:19.

21 Miner TJ, Shia J, Jaques DP, Klimstra DS, Brennan MF, Coit DG: Long-term survival following treatment of pseudomyxoma peritonei: an analysis of surgical therapy. Ann Surg 2005;241:300-308.

22 Esquivel J, Sugarbaker PH: Clinical presentation of the Pseudomyxoma peritone syndrome. Br J Surg 2000;87:1414-1418.

23 Gough DB, Donohue JH, Schutt AJ, Gonchoroff N, Goellner JR, Wilson TO, Naessens JM, O’Brien PC, van Heerden JA: Pseudomyxoma peritonei. Long-term patient survival with an aggressive regional approach. Ann Surg 1994;219:112-119.

24 Mayes GB, Chuang VP, Fisher RG: CT of pseudomyxoma peritonei. AJR Am J Roentgenol 1981; 136:807-808.

25 Seshul MB, Coulam CM: Pseudomyxoma peritonei: computed tomography and sonography. AJR Am J Roentgenol 1981:136:803-806.

26 Sulkin TV, O'Neill H, Amin AI, Moran B: CT in pseudomyxoma peritonei: a review of 17 cases. Clin Radiol 2002;57:608-613.

27 Sugarbaker PH: Cytoreductive surgery and perioperative intraperitoneal chemotherapy as a curative approach to pseudomyxoma peritonei syndrome. Tumori 2001; 87:S3-S5.

28 Fann JI, Vierra M, Fisher D, Oberhelman HA Jr, Cobb L: Pseudomyxoma peritonei. Surg Gynecol Obstet 1993;177:441-447.

29 El Sayed S: Pseudomyxoma peritonei treated by radiotherapy. Clin Oncol (R Coll Radiol) 1990;2:120-122. 